\title{
Physiological Behaviour of Escherichia coli Grown in Opposing Gradients of Oxidant and Reductant in the Gradostat
}

\author{
By R. W. LOVITT AND J. W. T. WIMPENNY* \\ Department of Microbiology, University College, Cardiff, Newport Road, \\ Cardiff CF2 ITA, U.K.
}

(Received 29 September 1980; revised 1 April 1981)

\begin{abstract}
Gradients of nutrients are extremely common in nature, and this paper decribes changes in the physiology of Escherichia coli grown in the gradostat, a series of five linked vessels with opposing gradients of glucose and of oxygen plus nitrate. Most growth occurred at the aerobic and anaerobic ends of the system. High rates of respiration, high energy charge and high activities of various oxidative enzymes were seen in the two most aerobic vessels; however, oxygen provision was presumably poor, because nitrate reductase activities were also high in this region. Vessels 3 and 4 showed the lowest values for respiration rate, enzyme activity and energy charge, and cells here were both nutrient starved and possibly inhibited by nitrite. Vessel 5 was highly anaerobic, resulting in the presence of hydrogenase activity. It was concluded that cells found in different regions of the gradostat had undergone biochemical differentiation in spatial gradients of electron donors and acceptors.
\end{abstract}

\section{INTRODUCTION}

Oxygen and nitrate are important regulators of metabolism in many bacterial species, and such regulatory effects are clearly observed in facultative anaerobes such as Escherichia coli. Normally, investigations into regulatory changes in metabolism have used homogeneous closed (batch) or open (continuous) culture systems (Wimpenny, 1969). The chemostat is an example of the latter; it enables steady-state conditions to be established and the effects of systematically varying a single parameter to be studied. Usually, steady-state cultures are established at one oxygen or nitrate concentration and the organism's physiology is examined before establishing another steady state. In ecological terms, this system examines the response of the organism to temporal gradients in the concentration of oxygen or nitrate. In contrast, organisms growing in neighbouring niches in many natural environments respond to spatial solute gradients.

A system of interconnecting vessels modelling gradients of salinity was used by Cooper \& Copeland (1973) to investigate estuarine ecology. A bidirectional compound chemostat using the same principles and called the gradostat was developed independently by Lovitt \& Wimpenny $(1979,1981)$ to model opposing solute gradients using small laboratory fermentation vessels. In the experiments reported here, Escherichia coli was grown in the gradostat in opposing gradients of glucose and of oxygen plus nitrate, and the physiological responses of organisms in each vessel were investigated.

\section{METHODS}

Organism and media. Escherichia coli $\mathrm{K} 12$ was maintained on nutrient agar (Oxoid) slopes at $4{ }^{\circ} \mathrm{C}$. The basal growth medium contained in distilled water $\left(\mathrm{g} \mathrm{l}^{-1}\right)$ : Casamino acids (Difco), 5.0; $\mathrm{KOH}, 4.45 ; \mathrm{NH}_{4} \mathrm{Cl}, 2.65$; $\mathrm{KH}_{2} \mathrm{PO}_{4}, 10 \cdot 8$; and $\left(\mathrm{mg} \mathrm{l}^{-1}\right) \mathrm{MgSO}_{4} .7 \mathrm{H}_{2} \mathrm{O}, 50 ; \mathrm{MnCl}_{2} .4 \mathrm{H}_{2} \mathrm{O}, 0.5 ; \mathrm{FeSO}_{4} .7 \mathrm{H}_{2} \mathrm{O}, 2 \cdot 5 ; \mathrm{CaCl}_{2} .6 \mathrm{H}_{2} \mathrm{O}, 1.0$. Medium B1 additionally contained $5 \mathrm{~g}$ glucose $\mathrm{I}^{-1}$ (sterilized separately at $121^{\circ} \mathrm{C}$ for 15 min); medium B2 additionally contained $4.25 \mathrm{~g} \mathrm{NaNO}_{3} \mathrm{1}^{-1}$. 
Gradostat culture conditions. Five 11 glass fermenter vessels were linked in series bidirectionally and connected to medium reservoirs and to collecting vessels at each end of the array (Lovitt \& Wimpenny, 1981). One reservoir, connected to vessel 5 , contained medium B1; the second reservoir, connected to vessel 1 , contained medium B2. Media from each reservoir and between each vessel in one direction (against gravity) were pumped using a peristaltic pump. Medium travelled in the opposite direction by gravity over a number of weirs. Vessel 1 was sparged with filter-sterilized air $\left(11 \mathrm{~min}^{-1}\right)$. Each vessel was stirred magnetically and the temperature was controlled at $37^{\circ} \mathrm{C}$. The volume of culture in each vessel was $665 \pm 7 \mathrm{ml}$. The flow rate in each line was $196 \pm$ $0.5 \mathrm{ml} \mathrm{h}^{-1}$. The dilution rate for each vessel, since there were two media flows, was $2 F / V$, where $F$ is the flow rate for one line in $\mathrm{ml} \mathrm{h}^{-1}$ and $V$ is the vessel volume in ml. Thus the dilution rate was $0.59 \mathrm{~h}^{-1}$ and the mean residence time in any one vessel was $1.7 \mathrm{~h}$. A 51 culture of $E$. coli K12 was grown anaerobically on medium B1 and used to fill all five vessels. The gradostat was operated for $5 \mathrm{~d}$ until a steady state was reached as gauged by $\mathrm{pH}$ and turbidity measurements. The experiment was continued for a further $3 \mathrm{~d}$ and, subject to purity checks, the cells were collected and processed. During operation, vessel 1 was the only vessel receiving oxygen, and hence oxidant gradients were established decreasing from vessel 1 to vessel 5 . Glucose entered the array from vessel 5 , hence there was a gradient in reductant decreasing from vessel 5 to vessel 1 . All the vessels were sealed to allow gas transfer in the direction of vessel 5 to vessel 1 but not in the opposite direction. The composition of the media was designed to ensure that there were opposing gradients of oxidant and reductant and that at some point in the array sources of each of these would become limiting.

Growth parameters. Culture turbidity was used as an index of cell density. $A_{550}^{1 \mathrm{~cm}}$ measurements were determined with an MSE Spectro-plus spectrophotometer. Total counts were made on samples diluted in $4 \%(\mathrm{v} / \mathrm{v})$ formaldehyde using a Thoma counting chamber (Gallenkamp) as described by Postgate (1969). Samples diluted in quarter-strength Ringer solution (Oxoid) were incubated for $2 \mathrm{~d}$ at $37^{\circ} \mathrm{C}$ on $\mathrm{B} 1$ agar for viable count determinations (Postgate, 1969).

Chemical determinations. Chemical determinations were made on whole cultures sampled from each vessel and stored at $-15^{\circ} \mathrm{C}$ until assayed.

Glucose was estimated by the glucose oxidase method of Raabo \& Terkildsen (1960) using Sigma assay kit 510. Volatile and non-volatile fatty acids were determined by gas-liquid chromatography as described by Holdeman $e t$ al. (1972), using a Pye series 104 chromatograph and flame ionization detectors. Columns were packed with $5 \%$ FFAP on chromosorb G 80-100 mesh (AW-DCMS) (Jones Chromatography, Llanbradach, S. Glamorgan) and argon (Air Products, New Malden, Surrey) was the carrier gas.

Nitrate was estimated colorimetrically using brucine sulphate (American Public Health Association, 1971). Nitrite was determined colorimetrically after diazotization using the Griess-llosvay reagents (Mackereth et al., 1978).

Protein was estimated by the Lowry method and the protein content of whole cells was determined after alkaline pretreatment (Herbert et al., 1971). All analyses are expressed per unit protein of the relevant cell or cell fraction.

Respiration measurements. Oxygen uptake was measured polarographically on washed whole cells as described by Lloyd \& Brookman (1967), using an oxygen electrode (Rank Industries, London). $Q_{\mathrm{O}_{2}}$ values were expressed as $\mathrm{nmol} \mathrm{O}_{2} \min ^{-1}$ (mg cell protein) ${ }^{-1}$.

Adenine nucleotides and adenylate energy charge assays. Culture samples $(1 \mathrm{ml})$ taken directly from the culture vessel were extracted with chloroform. ATP, ADP and AMP were estimated in the extracts by the methods of Chapman et al. (1971) and Edwards et al. (1975). Adenylate energy charge was expressed according to Atkinson \& Walton (1967). The lower limit of the ATP assay was $0.1 \mathrm{pmol}$ in a total volume of $0.21 \mathrm{ml}$.

Cell breakage and fractionation. After washing, the cells were disrupted in a Hughes press (Hughes, 1951) and fractionated as described by Sapshead \& Wimpenny (1972).

Enzyme assays. Spectrophotometric assays were carried out on a Cary 14 recording spectrophotometer (Applied Physics Corp., Monrovia, Calif., U.S.A.).

Aconitase [citrate (isocitrate) hydro-lyase, EC 4.2.1.3], fumarase (L-malate hydro-lyase, EC 4.2.1.2) and isocitrate dehydrogenase [isocitrate: $\mathrm{NADP}^{+}$oxidoreductase (decarboxylating), EC 1.1.1.42] activities were determined in the supernatant fraction, and NADH oxidase activity in the particulate fraction, as described by Gray et al. (1967). Succinate dehydrogenase (succinate: phenazine methosulphate oxidoreductase, EC 1.3.99.1) was measured in the particulate fraction as described by Sapshead \& Wimpenny (1972). No attempt was made to correct for fumarate reductase activity which was probably present under anaerobic conditions. Hydrogenase $\left(\mathrm{H}^{+}\right.$:ferredoxin oxidoreductase, EC 1.18 .3 .1$)$ was determined manometrically using whole cells (San Pietro, 1955).

Nitrate reductase activity was measured in washed whole cell suspensions by monitoring the appearance of nitrite from nitrate when formate was used as electron donor. The reaction mixture was sampled at timed intervals and nitrite determined using the Griess-Ilosvay reagents (Mackereth et al., 1978). Each assay tube contained, in

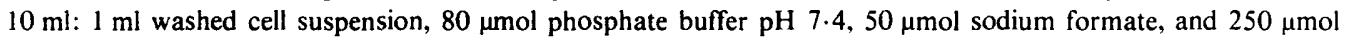
$\mathrm{NaNO}_{3}$; the tubes were incubated anaerobically for $15 \mathrm{~min}$. Samples $(1 \mathrm{ml})$, withdrawn at suitable intervals, were 
quenched in $4 \mathrm{ml} 0.25 \mathrm{M}$-acetic acid and nitrite was estimated as described above. Control assays showed no activity in the absence of formate or when nitrite replaced nitrate.

Cytochrome spectra. Cytochrome spectra were recorded using a Cary 14 recording spectrophotometer with $1 \mathrm{~cm}$ light path cuvettes. Dithionite-reduced minus ferricyanide-oxidized difference spectra and reduced (plus $\mathrm{CO}$ ) minus reduced (no $\mathrm{CO}$ ) difference spectra were recorded for the cell wall/membrane and soluble fractions. The concentrations of cytochromes present were estimated as absorbance ( $\mathrm{g}$ protein) ${ }^{-1}$.

\section{RESULTS}

The cell population. Although oxygen tension was not determined in these experiments, it was assumed that vessel 1 represented the most oxidizing or aerobic end of the array whilst vessel 5 represented the most reducing or anaerobic end. Steady-state cell population densities were measured in each of the five fermenter vessels (Fig. 1a). Total and viable cell counts indicated slightly more growth at the aerobic than the anaerobic end of the array. Viable counts were all lower than total counts but showed similar trends.

Solute concentrations. Glucose and some fermentation products were measured in each vessel (Fig. 1d). Glucose entered the gradostat at vessel 5, but no glucose was detected in the steady-state culture and it was concluded that glucose was limiting growth in this vessel. It was clear that a negligible amount of glucose was transferred to any other vessel in the array. Acetate, succinate and lactate were all present in vessel 5 and declined in concentration towards vessel 1 , where none was detected, suggesting that these products were oxidized at the expense of oxygen or nitrate at the aerobic end of the system. Measurements of $\mathrm{pH}$ confirmed that the aerobic end was less acidic; a pH of 7.8 was observed in vessel 1 and a pH of 6.6 in vessel 5 . A total carbon balance, assuming that carbon dioxide was fixed to make succinate, showed a linear distribution from the anaerobic end to the aerobic end of the system (Fig. 1d).

Nitrate, fed in from vessel 1 , was reduced in vessels 1,2 and 3, whilst its reduction product, nitrite, appeared in measurable amounts in all vessels. The most nitrite, however, was found in vessels 2, 3 and 4. (Fig. 1c).

Adenylates and adenylate energy charge. ATP, ADP and AMP concentrations were determined in the culture in each vessel and adenylate energy charge values were calculated (Fig. $1 b$ ). The restricted entry of a fermentable carbon source into vessel 5 and the entry of oxidant into vessel 1 suggested that growth would take place predominantly at the ends of the array. This view was borne out by the energy charge values, which were highest in vessels 1 and 5. Energy charge values fell consistently from 0.70 in vessel 1 to 0.35 in vessel 4 and rose back up to 0.57 in vessel 5 . The low value in vessel 4 , due mainly to a high level of AMP, suggested that cells in this vessel were energy limited.

Respiration rates. Potential respiration rates in washed cells from each vessel were determined with and without a number of substrates. The results from two separate gradostat runs are averaged in Fig. 2. Endogenous $Q_{\mathrm{O}_{2}}$ values were low - approximately $5 \mathrm{nmol} \mathrm{min}-1$ (mg protein $)^{-1}$ - and relatively constant in each vessel. However, the rates were increased significantly when substrates were added. The highest activity was recorded with formate: $118 \mathrm{nmol} \mathrm{min}^{-1}$ (mg protein $)^{-1}$ in vessel 1. Respiration rates on Casamino acids, glucose, succinate, lactate and fumarate rose to a peak in vessel 2. The $Q_{\mathrm{O}_{2}}$ values on Casamino acids, lactate and acetate stabilized in vessels 3 to 5 , whilst the values with glucose, succinate, fumarate and formate fell to a minimum level in vessel 3 and then rose again to a second peak of activity in vessel 5 .

Enzyme activities. The specific activities of various enzymes were determined. Mean values from two separate gradostat runs are shown in Fig. 3. Hydrogenase activity was observed only in vessel 5 . Nitrate reductase activity was highest in vessel 1 , with significant activity also found in vessel 2; only very low activities were recorded in vessels 3 to 5 . The high activities observed in vessels 1 and 2 coincided with high concentrations of nitrate in these 


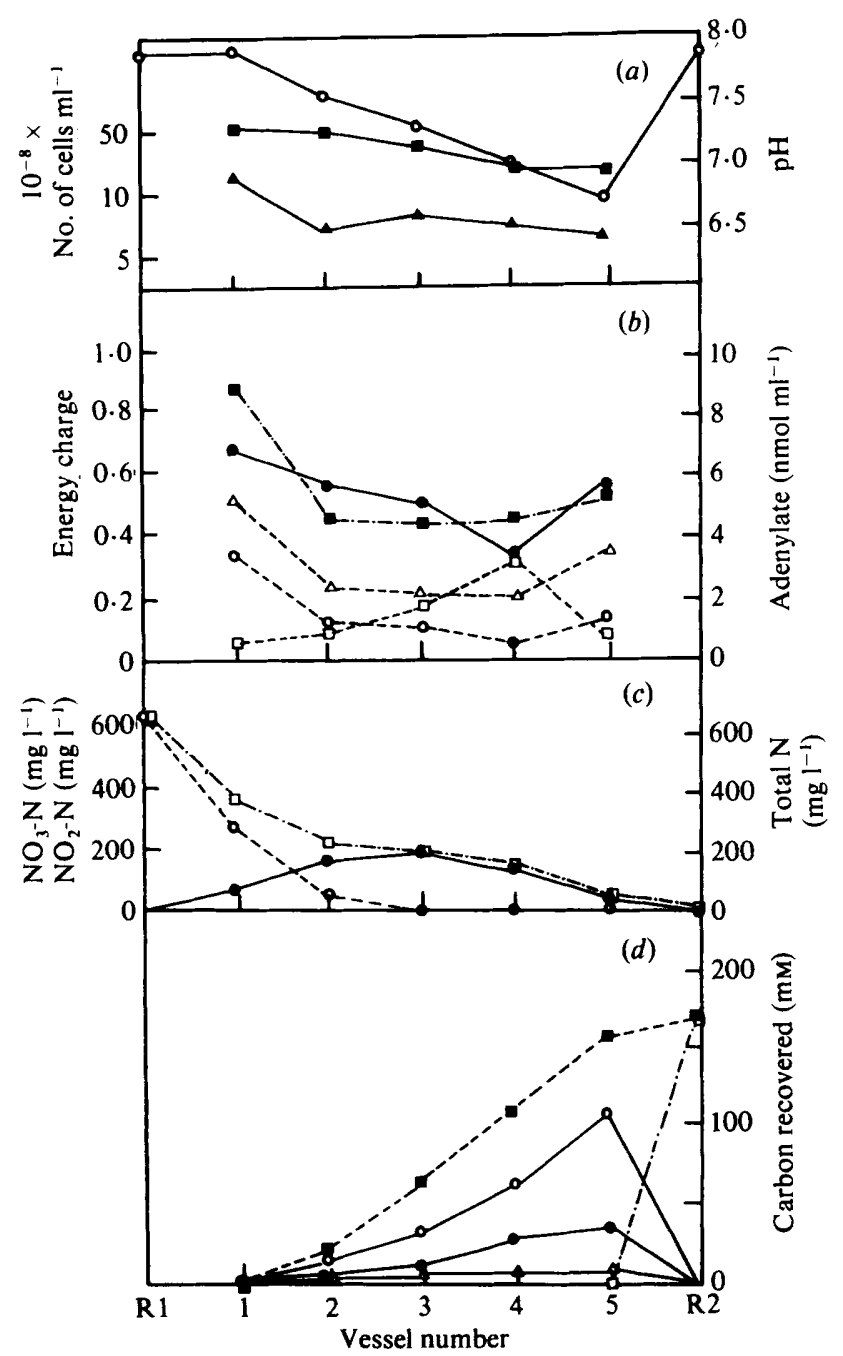

Fig. 1. Steady-state values for E. coli $\mathrm{K} 12$ grown in opposing gradients of glucose and oxygen plus nitrate in a five-element gradostat. $\mathrm{R} 1$ and $\mathrm{R} 2$ denote the medium reservoirs. (a) pH (O); total cell count $(\square)$; total viable count $(\Delta)$. (b) Adenylate energy charge (O); total adenylates ( $\square$ ); AMP ( $\square$ ); ADP $(O)$; ATP $(\triangle)$. (c) Nitrate $(O)$; nitrite $(O)$; total nitrogen $(\square)$. (d) Glucose $(\square)$; lactate $(\Delta)$; acetate $(\mathrm{O})$; succinate $(\mathrm{O})$ (all as carbon recovered); a total carbon balance, assuming that $\mathrm{CO}_{2}$ was fixed to make succinate, is also shown (D).

vessels. Aconitase activity was completely absent in vessel 3 and only low levels were observed in vessel 4. Succinate dehydrogenase and NADH oxidase activities showed similar profiles in that they were present at relatively low levels in vessel 3. Fumarase gave a similar pattern of low activity in vessels 3 and 4 . There also appeared to be a slight repression of fumarase, aconitase and succinate dehydrogenase activities in vessel 1 . The high activities of succinate dehydrogenase towards the anaerobic end of the gradostat may have represented fumarate reductase activity. Isocitrate dehydrogenase activity fell regularly towards the anaerobic end of the gradostat.

Cytochromes. Concentrations of cytochromes were determined in cell membrane and soluble fractions from broken cells (Fig. 4). Cytochromes $a_{1}, a_{2}, b_{558}$ and $o$ were present in the cell membrane fraction in measurable quantities. The low-potential cytochrome $c_{552}$ together 


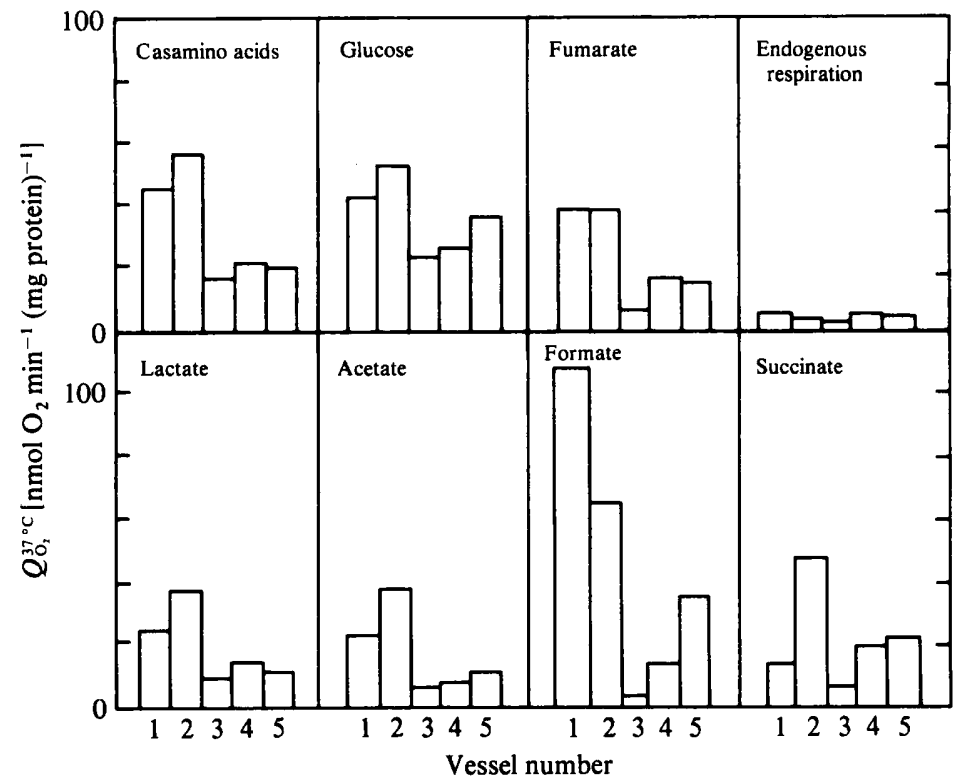

Fig. 2. Potential respiration rates for $E$. coli $\mathrm{K} 12$ grown in opposing gradients of glucose and oxygen plus nitrate in a five-element gradostat with or without various substrates.
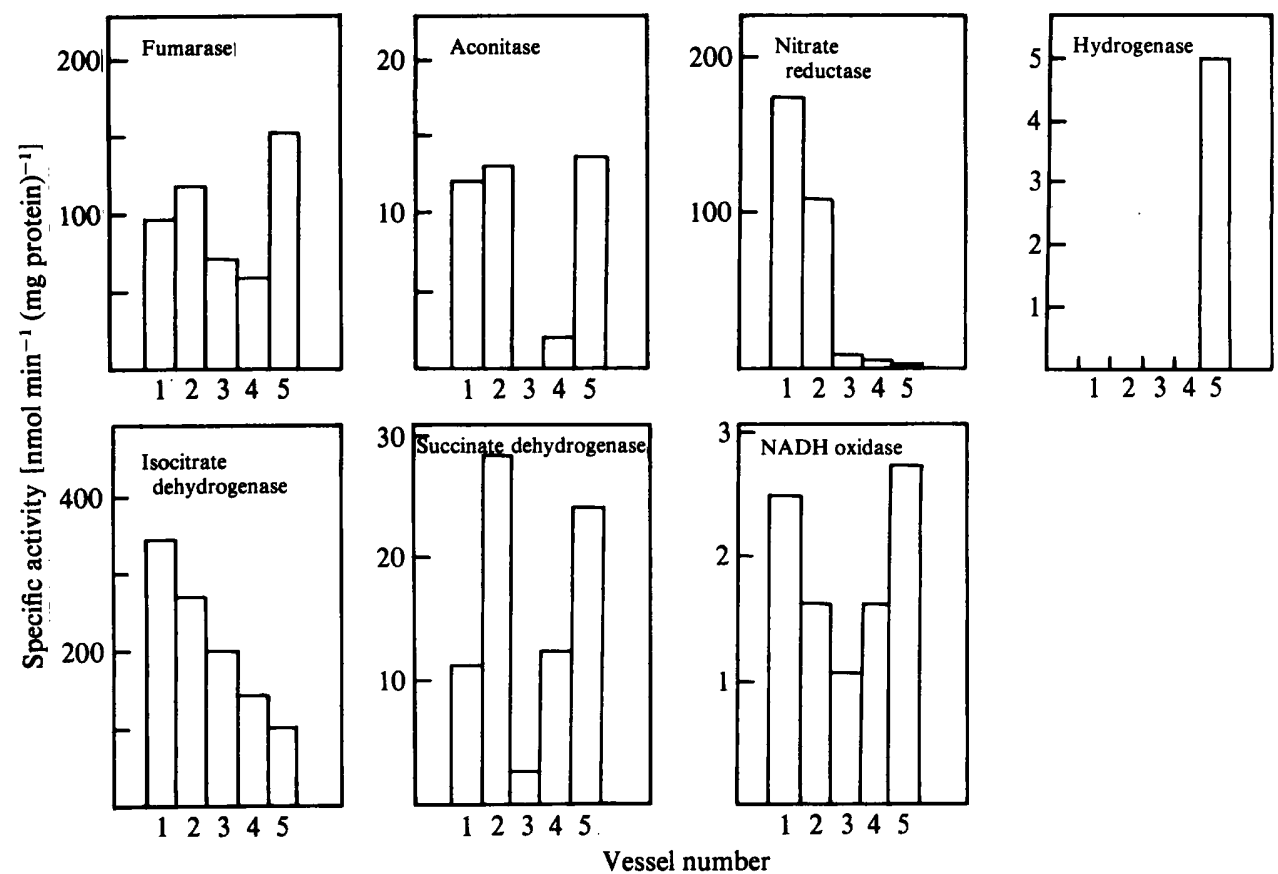

Fig. 3. Specific enzyme activities in cell fractions of $E$. coli $\mathrm{K} 12$ grown in opposing gradients of glucose and oxygen plus nitrate in a five-element gradostat.

with a $b$ type with a reduced $\alpha$ band at $558 \mathrm{~nm}$ were observed in the soluble fraction. Since the $c$ type cytochrome appeared as a shoulder on the $b$ peak, especially in the extracts from vessels 1 to 3 , the ratio of peak heights at the two wavelengths was used to try to resolve the 


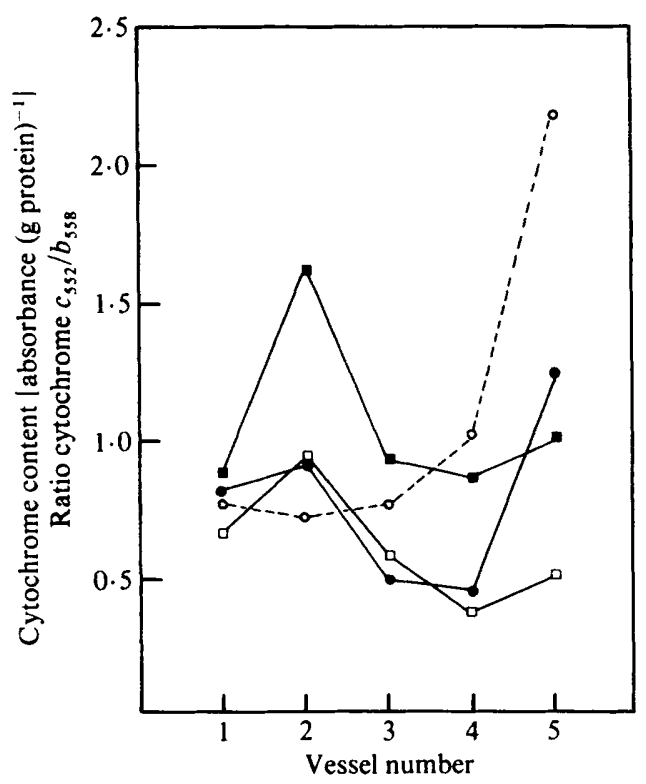

Fig. 4. Cytochrome contents of fractions of E. coli $\mathrm{K} 12$ grown in opposing gradients of glucose and oxygen plus nitrate in a five-element gradostat: cytochrome $b_{558}$ (scale reduced 10 times) ( $\square$ ); cytochrome $a_{1}(595 \mathrm{~nm})(0)$; cytochrome $a_{2}(630 \mathrm{~nm})(\square)$; ratios of soluble cytochrome $c_{552} /$ soluble cytochrome $b_{558}(\mathrm{O})$.

two. The ratio of the soluble $c_{552}$ to soluble $b_{558}$ rose consistently to a maximum in vessel 5 (Fig. 4). With minor variations cytochromes $a_{1}, a_{2}$ and $b_{558}$ varied together. All showed one peak in vessel 2, a trough in vessels 3 and 4 , and increased again in vessel 5. Cytochrome $a_{1}$, however, was present in highest amounts in vessel 5.

\section{DISCUSSION}

Emphasis on the use of open culture systems has tended to distract attention from the composition of natural microbial ecosystems, which are often spatially organized. Very few laboratory model systems incorporate elements of spatial organization. The gradostat provides a number of open linked vessels in which cells can proliferate under particular physicochemical conditions. Each vessel represents a single niche from which cells and solutes are transferred to and may interact with cells in neighbouring niches (Lovitt \& Wimpenny, 1981).

The experiments reported here demonstrate spatially organized biochemical differentiation in cells of Escherichia coli growing in opposing gradients of oxidants and reductant. Five separate niche spaces were available, with oxygen and nitrate entering the system at vessel 1 and glucose entering at vessel 5 . High total and viable cell counts and high energy charge values suggested that cells were growing actively in vessel 1 . The carbon sources here were Casamino acids and small amounts of glucose fermentation products. Cells showed high respiration rates, especially on formate. Poor oxygen transfer rates were probably responsible for the elevated activities of nitrate reductase, an enzyme normally repressed under aerobic conditions (Cole \& Wimpenny, 1966). Cells in vessel 1 were, therefore, oxygen limited and adapted to nitrate respiration. Vessel 2 showed high respiration rates and the highest levels of some respiratory enzymes and cytochromes. These cells were growing with excess nitrate in the presence of excess glucose fermentation products. Virtually no oxygen could enter this vessel and hence conditions were energetically less favourable than in vessel 1 . Vessels 3 and 
4 may be considered together. In these vessels there was no trace of a fermentable carbon source nor was there a high-potential electron acceptor such as oxygen or nitrate. In addition, nitrite, a toxic metabolite, was present in relatively high concentrations. Energy charge was at its lowest in vessel 4, suggesting that cells were starving in this region or that the high nitrite concentrations were toxic. The low activity of aconitase in vessel 3 may have been due to nitrite toxicity (Wimpenny \& Warmsley, 1968). Cells in vessels 3 and 4 showed the lowest respiratory activities and lowest activities of several of the enzymes assayed. Cells in vessel 5 had clearly adapted to anaerobic conditions, as characterized by the presence of hydrogenase (Pichinoty, 1962). No nitrate and only small amounts of nitrite were present in this vessel: both acceptors are capable of inhibiting and repressing hydrogenase (Cole \& Wimpenny, 1966). The ratio of soluble cytochrome $c_{552}$ to soluble cytochrome $b_{556}$ increased sharply in vessel 5, also correlating with anaerobic conditions (Gray et al., 1963). High levels of succinate oxidizing activities may reflect an increase in fumarate reductase anaerobically (Hirsch et al., 1963); however, other, more characteristically aerobic, enzymes were also present in vessel 5 (aconitase, NADH oxidase and fumarase) and there is at present no simple explanation for all of the experimental data. Total and viable counts and energy charge values suggested that active growth took place in vessel 5.

One of us (R.W.L.) gratefully acknowledges a research studentship from Esso Research Ltd, Abingdon, Oxfordshire.

\section{REFERENCES}

American Public Health Association (1971). Standard Methods for the Examination of Water and Waste Water, 13th edn, pp. 461-464.

AtKInSON, D. E. \& Walton, H. W. (1967). Adenosine triphosphate conversion in metabolic regulation. Journal of Biological Chemistry 193, 265-275.

Chapman, A. G., Fall, L. \& Atkinson, D. E. (1971). Adenylate energy charge in $E$. coli during growth and starvation. Journal of Bacteriology 108, 1072 1086.

Cole, J. A. \& WImpenny, J. W. T. (1966). The inter-relationships of low redox potential cyto-chrome $c_{s 52}$ and hydrogenase in facultative bacteria. Biochimica et biophysica acta 128, 419-425.

CoOper, D. G. \& Copeland, B. J. (1973). Responses of a continuous series of estuarine microecosystems to point-source input variations. Ecological Monographs 43, 213-236.

Edwards, C. V., Statham, M. \& Lloyd, D. (1975). The preparation of large-scale synchronous cultures of the trypanosomatid, Crithidia fasciculata, by cell size selection: changes in respiration and adenylate charge through the cell-cycle. Journal of General Microbiology 88, 141-152.

Gray, C. T., WimpenNy, J. W. T., Hughes, D. E. \& RANLETT, M. R. (1963). A soluble $c$ type cytochrome from anaerobically grown Escherichia coli and various Enterobacteriaceae. Biochimica et biophysica acta 67, 157-160.

Gray, C. T., WImpenNy, J. W. T., Hughes, D. E. \& Mossman, M. R. (1967). Regulation of metabolism in facultative bacteria. I. Structural and functional changes in Escherichia coli associated with shift between the aerobic and anaerobic states. Biochimica et biophysica acta 117, 22-32.

Herbert, D., Phipps, P. J. \& Strange, R. E. (1971).
Chemical analysis of microbial cells. Methods in Microbiology 5B, 209-344.

HiRsch, C. A., RAsminski, M., Davis, B. D. \& LiN, E. C. C. (1963). A fumarate reductase in Escherichia coli distinct from succinate dehydrogenase. Journal of Biological Chemistry 238, 3770-3774.

holdeman, L. V., Cato, E. P. \& Moore, W. E. C. (1972). V.P.I. Anaerobe Laboratory Handbook. Blacksburg, Virginia: Virginia Polytechnic Institute and State University.

Hughes, D. E. (1951). A press for disrupting bacteria and other micro-organisms. British Journal of Experimental Pathology 32, 97-109.

LloYd, D. \& Brookman, J. G. S. (1967). An oxygen electrode reaction vessel. Biotechnology and Bioengineering 9, 271-272.

LovitT, R. W. \& WIMPENNY, J. W. T. (1979). The gradostat: a tool for investigating microbial growth and interactions in solute gradients. Society for General Microbiology Quarterly 6, 80.

LovitT, R. W. \& WIMPENNY, J. W. T. (1981). The gradostat: a bidirectional compound chemostat and its application in microbiological research. Journal of General Microbiology 127, 261-268.

Mackereth, F. S. M., Heron, J. \& Talling, J. F. (1978). Water Analysis. Freshwater Biological Association Scientific Publication No. 36.

Pichinoty, F. (1962). Inhibition par l'oxygène de la biosynthèse et de l'activité de l'hydrogènase et l'hydrogènlyase chez les bactéries anaérobies facultatives. Biochimica et biophysica acta 64, 111-124.

Postgate, J. R. (1969). Viable counts and viability. Methods in Microbiology 1, 611-628.

RAABO, E. \& TERKILDSEN, T. C. (1960). On the enzymatic determination of blood glucose. Scandinavian Journal of Clinical and Laboratory Investigation 12, 402-407 
San Pietro, A. (1955). Assay and properties of hydrogenase. Methods in Enzymology 2, 861-870.

SAPShEAD, L. \& Wimpenny, J. W. T. (1972). The influence of oxygen and nitrate on the formation of cytochrome pigments of aerobic and anaerobic respiratory chains of Micrococcus denitrificans. Biochimica et biophysica acta 267, 388-397.

WIMPENNY, J. W. T. (1969). Oxygen and carbon dioxide as regulators of microbial growth and metabolism. Symposia of the Society for General Microbiology 19, 161-197.

WIMPENNY, J. W. T. \& WARMSLEY, A. M. H. (1968).

The effect of nitrate on Krebs cycle enzymes in various bacteria. Biochimica et biophysica acta 156, 297-303. 